\title{
Incidence of Bacterial Pathogens Causing Infection in Equine Reproductive Tract
}

\author{
K. Balamurugan ${ }^{1 *}$, S. Subapriya ${ }^{2}$, N. M. Dinesh ${ }^{1}$ and P. Partheban ${ }^{1}$ \\ ${ }^{1}$ Kunigal Stud farm, Kunigal, Karnataka, India \\ ${ }^{2}$ Centralized Clinical Laboratory, Madras Veterinary College, Chennai, India \\ *Corresponding author
}

\begin{tabular}{|c|c|}
\hline & A B S T R A C T \\
\hline $\begin{array}{l}\text { Equine } \\
\text { reproduction, } \\
\text { Reproductive } \\
\text { pathogens, } \\
\text { Isolation, } \\
\text { identification }\end{array}$ & \multirow{3}{*}{$\begin{array}{l}\text { Uterine infection is one of the main causes of equine infertility in } \\
\text { thoroughbred mares. A timely diagnosis and an efficacious treatment in the } \\
\text { breeding season would be essential for a successful breeding outcome. The } \\
\text { current study was to identify the bacterial infection based on growth in } \\
\text { culture media. In one season out of } 107 \text { mares, } 45 \text { mares }(42 \%) \text { were } \\
\text { positive for culture and } 62 \text { mares }(58 \%) \text { were negative for any pathogens. A } \\
\text { total of } 216 \text { cervical swabs were taken. Seventy sample }(32 \%) \text { were } \\
\text { positive for culture and } 146(68 \%) \text { were negative. In that } 64(91 \%) \text { cultures } \\
\text { were contained only single type of organism and } 6(9 \%) \text { cultures were } \\
\text { mixed colonies that had two types of organism. In our study, Escherichia } \\
\text { coli was the major isolate followed by Staphylococcus spp. and } \\
\text { Streptococcus spp. beta haemolytic group. }\end{array}$} \\
\hline Article Info & \\
\hline $\begin{array}{l}\text { Accepted: } \\
\text { 20 August } 2020 \\
\text { Available Online: } \\
10 \text { September } 2020\end{array}$ & \\
\hline
\end{tabular}

\section{Introduction}

Asbury (1986) stated that uterine infections had long been recognized as one of the major causes of reduced fertility in the mare. This leads to major losses in equine industry. The expenses of breeding, rectal palpation, ultrasonography, boarding, mare transport, semen shipment and stallion collection fees could never be recovered if a mare failed to conceive (Samper et al., 2007). Potentially pathogenic organisms were introduced during natural breeding, artificial insemination, during and after parturition, during examination and as a result of failure of physical barriers to infection. When uterine defense mechanisms function properly, they clear bacterial infection without interfering reproduction (Frontoso et al., 2008).

Bacterial uterine infections were the major loss in the equine breeding industry occurring in 25-60\% of barren mares (Bain, 1966 and Collins, 1964). Benko et al., (2015) stated that 69.7 percent of cervical swabs were positive for pathogenic micro-organisms; of those (307 positive findings) 40.4 percent contained $\beta$-haemolytic streptococci and 20.4 percent 
Escherichia coli (19.5\% non-haemolytic, $5.9 \%$ haemolytic). Since horses are seasonal breeders, it is very important to diagnose and treat the uterine infections as soon as possible to get early foals.

\section{Materials and Methods}

\section{Study population}

This study was conducted in a thoroughbred stud farm located in South India. A Total of 107 mares were included in this study. Cervical swabs were taken when the mares were in season and the cervix was relaxed. Repeatability of mares is common because not all the mares are having chance to become pregnant in single covering. Finally 216 culture samples were taken for this study.

\section{Clinical examination and collection of samples}

Mares were looked for any vaginal discharge. Since the vestibule is long in mares, mild to moderate discharges are not seen outside. Usually some mares look apparently normal, but while doing rectal examination vaginal discharge was seen because of the back racking.

Perineum was washed thoroughly with $0.1 \%$ Povidone Iodine solution in cotton and dried. Sterilized vaginal speculum was inserted into the vagina and cervix was examined for relaxation, discharge and any post foaling bruises. Sterile swab stick was introduced into cervix approximately $5 \mathrm{~cm}$ deep. Swabs were collected by rotating them clock wise and anti-clock wise to obtain adequate sample. It was made sure that the swab stick did not touch any other part other than cervix (Figure $1)$.

\section{Isolation of organism}

Within one hour of sampling, swabs were smeared on sheep blood agar and McConkey agar. These agar plates were used for isolating, cultivating and determining hemolytic reactions of pathogenic microorganism. Plates were inverted and incubated at $37^{\circ} \mathrm{C}$ and examined 24 hours and 48 hours. After 48 hours the culture samples were categorized either as substantial growth or no growth or contaminated.

Fig

\begin{tabular}{|l|l|}
\hline Figure. 1 Speculum examination shows relaxed \\
\hline cervix
\end{tabular}




\section{Results and Discussion}

A total of 216 cervical swabs were taken in this study. Seventy sample (32\%) were positive for culture and $146(68 \%)$ were negative and Forntoso et al., (2008) found $49 \%$ positive at bacteriological investigations in their study.

In that $64(91 \%)$ cultures were contained single type of organism and $6(9 \%)$ cultures were mixed colonies that had two types of organism. Thirty four samples $(49 \%)$ had $E$. coli (Figure 2 and 3), 19 samples (27\%) had Staphylococcus spp. (Figure 4) and 11 samples (16\%) had Streptococcus spp. beta haemolytic group (Figure 5). Three samples (4\%) had E. coli + Staphylococcus spp., (Figure 6) 2 samples (3\%) had Streptococcus spp. beta haemolytic group + Staphylococcus spp. and one sample (1\%) had E. coli + Streptococcus spp. beta haemolytic group.

Streptococcus spp. were the most common isolates found by Forntoso et al., (2008) and Riddle et al., (2007) with $31.7 \%$ and $34 \%$ respectively and $E$. coli was the second isolate in their study. Wingfield Digby and Ricketts (1982), LeBlanc et al., (2007) and Dascanio (2011) also showed that Streptococcus spp. was the most common bacteria isolated from mare's reproductive tract. But in our study, $E$. coli was the major isolates followed by Staphylococcus spp. and Streptococcus spp. beta haemolytic group. Albihn et al., (2003) also stated that $E$. coli was most frequently associated with fertility problems and beta haemolytic Streptococci were the second most frequent. This may be due to variations in the geography and climate.

\section{References}

Albihn, A., V. Baverud, and U. Magnusson, 2003. Uterine Microbiology and Antimicrobial Susceptibility in Isolated
Bacteria from Mares with Fertility Problems. Acta vet. scand., 44: 121-129.

Asbury, A.C., 1986. Endometritis in the mare. In: Current Therapy in Theriogenology. Ed: Morrow DA, WB Sounders, Philadelphia, USA, pp.718-722.

Bain, A.M., 1966. The role of infection in infertility in the thoroughbred mare. VET REC., 78: 168-175.

Benko, T., M. Boldizar, F. Novotny, V. Hura, I. Valocky, K. Dudrikova, M. Karamanova and V. Petrovic, 2015. Incidence of bacterial pathogens in equine uterine swabs, their antibiotic resistance patterns, and selected reproductive indices in English thoroughbred mares during the foal heat cycle. Veterinarni Medicina, 60(11): 613-620.

Collins, S.M., 1964. A study of the incidence of cervical and uterine infection in Thoroughbred Mares in Ireland. VET REC., 76: 673-676.

Dascanio, 2011. How and when to treat endometritis with systemic or local antibiotics. AAEP proceedings., 57: 2431.

Frontoso, R., E. De Carlo, M.P. Pasolini, K. van der Muelen, U. Pagnini, G. Iovane and L. De Martino, 2008. Retrospective study of bacterial isolates and their antimicrobial susceptibilities in equine uteri during fertility problems. Vet. Sci. Res. J., 84: 1-6.

LeBlanc, M.M., J. Magsig and A.J. Stromberg, 2007. Use of low volume uterine flush for diagnosing endometritis in chronically infertile mares. Theriogenol., 68: 403-412.

Riddle, W.T., M.M. Le Blanc, and A.J. Stromberg, 2007. Relationships between uterine culture, cytology and pregnancy rates in a Thoroughbred practice. Theriogenol., 68:395-402.

Samper, J.C., J.F. Pycock, and A.O. McKinnon, 2007. Uterine Therapy for 
Mares with Bacterial Infections. In: Current Therapy in equine reproduction. Saunders Elsevier. St. Louis, Missouri. pp. 105-115.

Wingfield Digby, N.J and S.W. Ricketts, 1982. Results of concurrent bacteriological and cytological examinations of the endometrium of mares in routine stud farm practice. $J$. Reprod. Fert., Suppl., 32: 181-185.

\section{How to cite this article:}

Balamurugan, K., S. Subapriya, N. M. Dinesh and Partheban, P. 2020. Incidence of Bacterial Pathogens Causing Infection in Equine Reproductive Tract. Int.J.Curr.Microbiol.App.Sci. 9(09): 3132-3135. doi: https://doi.org/10.20546/ijcmas.2020.909.386 